\title{
The Structure of Banking Systems in Developed and Transition Economies
}

\section{Dwight Jaffee}

Haas School of Business, University of California, Berkeley and Federal Reserve Bank of San Francisco,

e-mail: jaffee@haas.berkeley.edu

\section{Mark Levonian}

Federal Reserve Bank of San Francisco,

e-mail: Mark.Levonian@sf.frb.org

\begin{abstract}
The paper empirically analyses the determinants of banking system structure (as measured by bank assets, number, branches and employees) for 26 developed OECD countries. The estimated regressions are then applied to 23 transition economies, to obtain benchmarks for the efficient structure of their banking systems. The actual and benchmark measures of banking structure are compared to evaluate the state of banking system development, including the computation of a measure of 'banking system convergence'. The results are objective and replicable multidimensional measures of banking system development for the transition economies.
\end{abstract}

Keywords: banks; banking systems; banking structure; transition economies; developing economies.

JEL classification: $G 21, O 16, P 34$

\section{Introduction}

The economic development literature has long attributed a key role to a country's banking sector, going back at least to Schumpeter (1911). Recent papers by Levine and Zervos (1998) and Rajan and Zingales (1998) address aspects of the connection between the banking and financial system and economic growth. In the recent literature, banking system development has been measured with simple and accessible

Views expressed are the authors' and do not represent official positions of the Federal Reserve.

We would like to thank the participants at the bank privatisation seminar held at the Federal Reserve Bank of Dallas, March 15, 1999, and especially the seminar organisers Jo Ann Paulson of the World Bank and Harvey Rosenblum of the Dallas Federal Reserve, the European Financial Management Association 2000 Meetings, Athens, Greece, for very helpful comments on an earlier draft of this paper. Corresponding author Professor Dwight Jaffee, Haas School of Business, University of California, Berkeley California, 94720-1900, USA. 
ratios, such as the ratio of bank loans to GDP, reflecting a primary focus on such questions as the direction of causation and the role of other financial markets. However, a banking system has many different structural dimensions, which are difficult to capture in one simple measure. Banking assets may be housed in a few banks or many, with a few branches per bank or a large number of such offices. Moreover, the use of a single measure generally presumes that the relationship is monotonic, that is that higher values of the banking-structure variable are necessarily better. While this may be true in early stages of economic development when the banking system clearly is underdeveloped, at some point banking systems reach optimal or efficient structure, beyond which further expansion produces minimal benefits for economic growth (and may even be counterproductive).

In this paper, we develop a new and detailed set of benchmark measures of banking system structure for a number of developing transition economies, and compare our benchmarks with other available measures. We can then measure banking system development relative to these benchmarks, to take into account the possibility that 'more' is not necessarily 'better'. In contrast to the economic growth literature, which takes the banking system structure as given, our focus is on the factors that determine banking system structure. Our goal is to provide objective and replicable multidimensional measures of banking system development for the transition economies, which can then be applied to questions of economic growth in these countries.

The focus on the transition economies of Central and Eastern Europe is another unique element of this paper. Detailed measures of banking sector development in the transition economies are particularly important because the process of creating these banking systems has varied substantially across the countries, ranging from the privatisation of state-owned banks (frequently former subsidiaries or divisions of the central bank) to the 'free chartering' of new banking institutions. Furthermore, since the process is often administrative rather than market-driven, there is no assurance that the resulting industry structure will be efficient; there has been little evaluation of these evolving banking systems.

The basic method of this paper involves two stages. In the first stage, we carry out cross-section regression tests to determine the most important proximate causes of the observed structure of banking systems in developed economies. In the second stage, we apply the regressions estimated in the first stage to 23 transition economies, to obtain benchmarks for the efficient structure of the banking systems in these countries. A comparison of the actual and benchmark measures then provides a basis for evaluating the state of development of the banking systems in the transition economies. This methodology assumes that the banking systems in the developed economies have reached an efficient equilibrium and that the observed cross-country variations in banking system structure can be related in a dependable way to the distinctive economic, demographic, financial, and geographic features of each of these countries and their economies.

The literature on the determinants of banking system structure is very limited; we have found only two empirical studies for the United States and several qualitative studies for European banking systems. Berger et al. (1995) estimated equations for the number of banking institutions for a cross-section of the states in the United States, in order to evaluate the transformation of the US banking system in view of the removal of prohibitions against interstate banking. Kaufman and Mote (1994) successfully estimated an equation for another aspect of banking structure, the number of branches, for a cross-section of Chicago neighbourhoods based on the income, 
population, and area of the neighbourhoods. On an international basis, the available studies are mainly descriptive, including a number of recent books that discuss the expected changes in European banking systems as a result of integration of financial systems within the European Union. ${ }^{1}$

The rest of the paper is structured as follows:

- Section 2 describes the conceptual framework that underlies the equations that are to be estimated for the structure of banking systems. The section also provides the regression estimates of banking system structure for the developed countries. Separate equations are estimated for bank assets, the number of banks, number of branches, and bank employees.

- Section 3 applies the estimated equations to compute benchmarks for the banking system structure in transition economies. We also compare these benchmarks with the current actual values for those countries.

- Section 4 provides conclusions.

- An appendix provides a complete description of the data sources.

\section{An Empirical Model of Banking Sector Structure}

The structure of a country's banking system should evolve to a form that efficiently provides banking services, given the distinctive economic, demographic, financial, and geographic features of the country. Three main categories of banking services can be identified:

(1) Payment system services, which relate to the circulation of currency and the provision of demand deposit accounts and other forms of third party transfer.

(2) Intermediation services, which expedite the transfer of financial resources from savers (who hold bank deposits) to investors (who take out bank loans).

(3) Investment banking services, which may range from selling and managing mutual funds to providing financial services to firms.

In an efficient banking system, each of these services will be supplied up to the level at which the marginal benefit to bank customers equals the marginal cost to the bank of providing the service. This requires, of course, that the prices for bank services be set in free and competitive markets. Otherwise, banks with substantial market power may provide too few banking services, and banks constrained by regulations may provide too many banking services (such as the large number of banking offices created in the United States when Regulation Q deposit rate ceilings were in effect). Although bank competition in developed countries might not always be characterised as vigorous, they are highly competitive relative to banking systems in developing countries.

With competitive markets and a shared technology across countries for providing banking services, the demand for banking services is the primary determinant of the quantity supplied on a cross-country basis. The demand depends in turn on the more fundamental economic, demographic, and geographic features of each country. To capture the differences across countries that may affect the demand for banking services (and hence the structure of the banking system), we use five

\footnotetext{
${ }^{1}$ See, for example, Dermine (1993), Kaufman (1992), Lewis and Pescetto (1996), and Pawley (1993).
} 
exogenous variables: ${ }^{2}$

GDP: $\quad$ Gross domestic product (in US\$ millions)

Pop: $\quad$ National population (in thousands)

Area: $\quad$ Size of country (in square miles)

Foreign: Ratio of non-resident claims to total claims on banks

GSR: Gross saving ratio (the ratio of gross savings to GDP)

The variables and data are described more completely in the data appendix.

These exogenous variables influence the demand for banking services through various channels. For example, GDP, Pop, and Area should have a strong influence on the demand for payment system services. ${ }^{3}$ The demand for intermediation services might depend primarily on the level of a country's wealth and on the annual additions to its wealth; GDP could serve as a proxy for the level of wealth, and the gross saving rate $G S R$ as a proxy for the annual additions to wealth. Similarly, the demand for investment banking services may depend on the level of a country's GDP, and to a lesser degree its gross saving rate. Foreign demand may have a strong influence on the provision of banking services, especially intermediation and investment banking. Some countries, such as Switzerland or Luxembourg, serve as international banking centers; these countries have a high percentage of total bank liabilities that are due to foreigners, as measured by the variable Foreign.

The structure of the banking system is determined by the exogenous variables through their influence on the demand for various banking services. We use four variables to measure banking system structure:

Assets: $\quad$ Value of banking assets (in US\$ millions)

Banks: $\quad$ Number of banking institutions

Branches: Number of full-service banking offices

Employees: Number of banking employees (in thousands)

Data for the measures of banking structure come from a sample of 26 OECD countries for the year $1995 .{ }^{4}$ We have chosen the OECD data because it represents the most complete and comparable data set for our four banking system measures. Banking data for each country cover all banking organisations, including commercial banks, savings banks (including savings and loan associations and building societies), and cooperative banks, but excluding credit unions. The data are described more completely in the appendix.

The magnitude of each of these structural measures depends on the relative demand for each of the types of banking services. For example, we might expect the magnitude of banking system assets to depend critically on the demand for intermediation

\footnotetext{
${ }^{2}$ Of course, these variables are not truly exogenous; variables like GDP, GSR, and Foreign likely depend to some extent on the nature of a country's banking system.

${ }^{3}$ GDP and population should be key determinants of the level of activity and the number of transactions that occur in an economy, with greater geographic dispersion of activity (as measured by Area) also creating greater need for a more sophisticated array of payments services.

${ }^{4}$ Although the Czech Republic, Hungary, and Poland are now part of the OECD data set, they have been excluded from the OECD sample because they are included in the transition country data sample analysed in Section 3.
} 
services, since intermediation is likely to be more asset intensive than payment system activities and investment banking. Similarly, the number of branches might depend much more on the demand for payment system services than on the demand for intermediation services or investment banking services.

\section{Banking sector structure in the developed OECD countries}

Simple ratios provide both a description of the dataset and a starting point for illustrating the relationships across the 26 developed OECD countries. Figure 1 shows the ratio of bank assets to GDP. Luxembourg stands alone on this measure, with an asset to GDP ratio over 40, while the other countries range from Turkey (ratio of 0.4 ) to Switzerland (ratio of 4.0). The wide variation in the asset to GDP ratio across developed economies also indicates that this ratio alone is not a sufficient indicator of the contribution of the banking system to a country's economic growth. For example, since the top four countries in Figure 1 (Luxembourg, Switzerland, Belgium and UK) are all international banking centers, it is apparent that the variable Foreign is likely to be an important determinant of bank assets. More generally, the variation in the asset to GDP ratio across all of the countries indicates a strong need for a multivariate analysis in which several exogenous variables are likely to co-determine bank assets.

Figure 2 shows the the ratio of total banking system assets to the number of banks, that is, the average bank size. Assuming that the technology for producing banking services is roughly similar, then we would expect banks to be approximately the same size across countries. Figure 2 shows, however, that the average size of banks varies widely across the OECD sample, ranging from $\$ 120$ million per bank in Iceland to

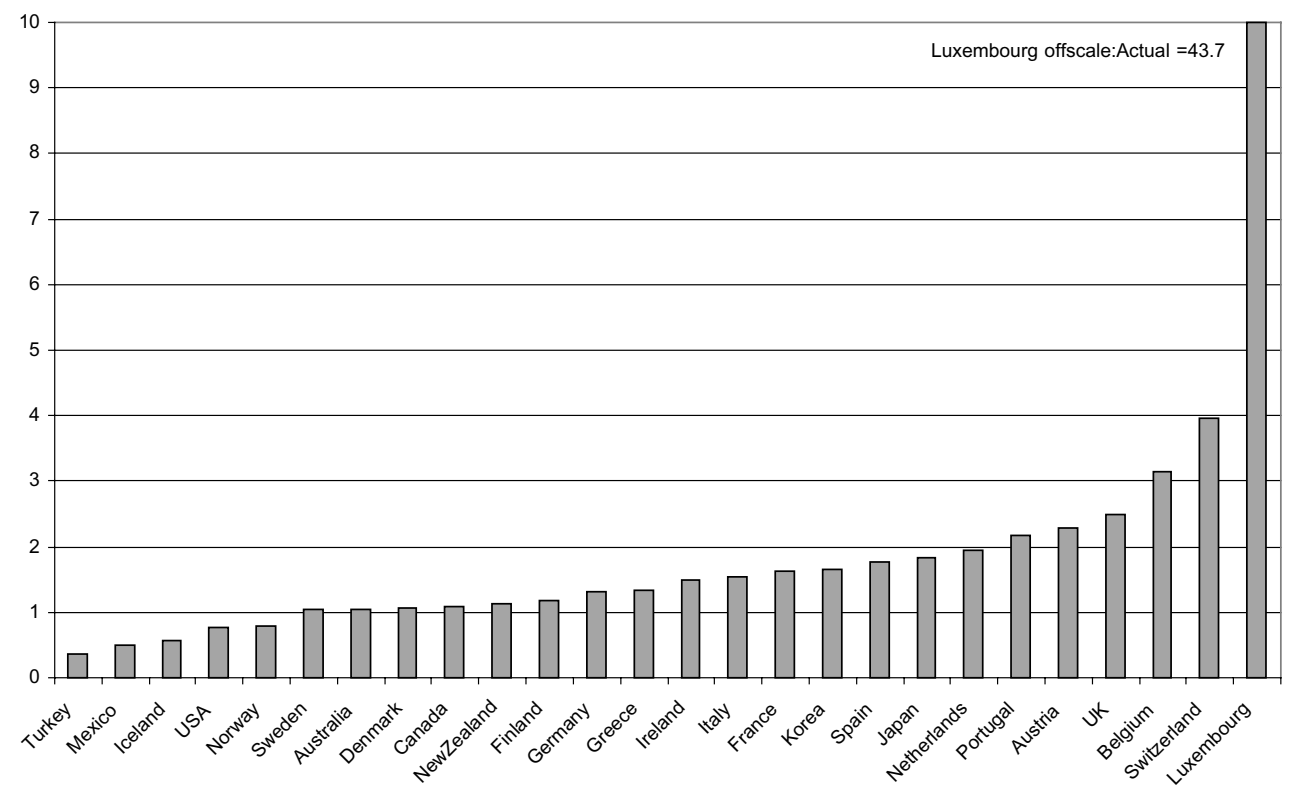

Fig. 1. Ratio of assets to gross domestic product (GDP), OECD countries (Based on data for all banks, 1995). 


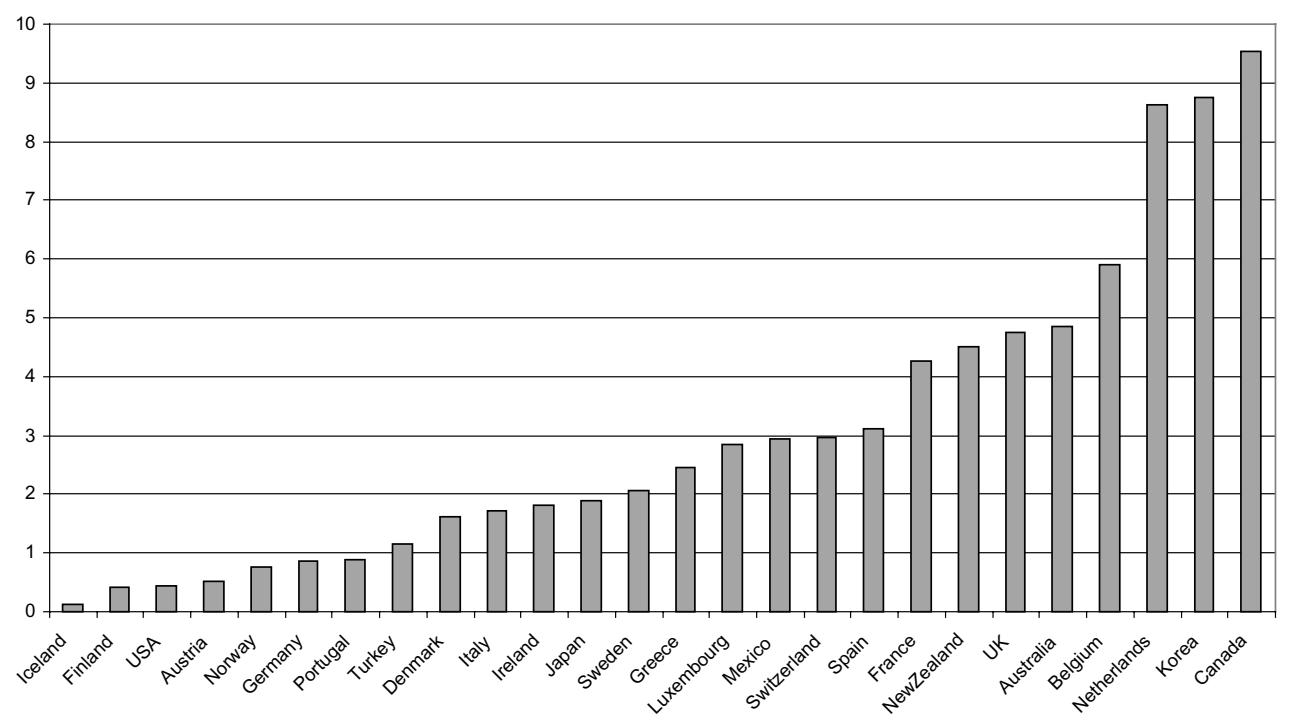

Fig. 2. Assets per bank, OECD countries, (US\$ billions)

(Based on data for all banks, 1995).

almost $\$ 10$ billion per bank in Canada, suggesting the important role of regulatory and political factors.

Figure 3 shows the ratio of the number of bank branches to GDP (in US\$ billions) for the OECD sample. This ratio also covers a very wide range, suggesting that there is no simple proportionality relationship between GDP and the number of branches, as would be indicated by constant ratio across countries. Specifically, the two richest

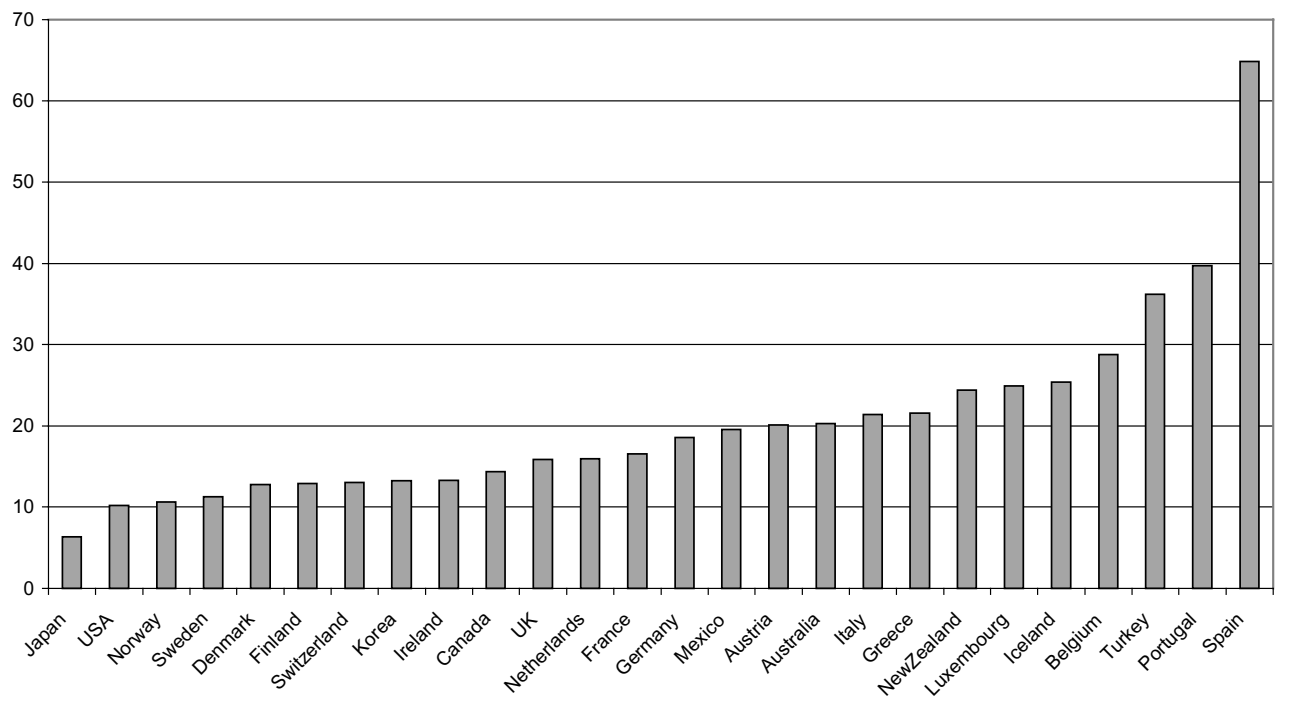

Fig. 3. Ratio of branches to GDP (US\$ billions), OECD countries (Based on data for all banks, 1995). 
countries, Japan and the United States, have the highest GDP and the lowest branch to GDP ratio, emphasising that the number of branches does not rise proportionately with income. Again, these variations suggest the need for a multivariate analysis.

Figure 4 shows that the employee to branch ratio ranges from a low of 7 employees per branch in Spain to almost 60 employees per branch in Luxembourg. This wide variation across countries may reflect differences in the type of banking services demanded in each country.

\section{Estimation of banking structure equations}

The wide variation across countries of the ratios in Figures 1-4 makes it unlikely that these structural measures are proportional to some single underlying variable like GDP or country size. In this section, we estimate multivariate regressions for the various measures of banking system structure in developed countries. All of the equations are estimated over the cross-section sample of 26 developed OECD countries for the year 1995. The equations are estimated using ordinary least squares. All variables are in logs, except for the ratio variables GSR and Foreign; thus, the coefficients generally can be interpreted as elasticities. ${ }^{5}$ The absolute values of $t$ statistics are shown below the estimated coefficients in all tables.

Table 1 shows estimated equations for each of the four banking structure variables as a function of all 5 exogenous variables. Each of the variables is defined in a way that makes the expected sign on its coefficient positive. The equations for Assets,

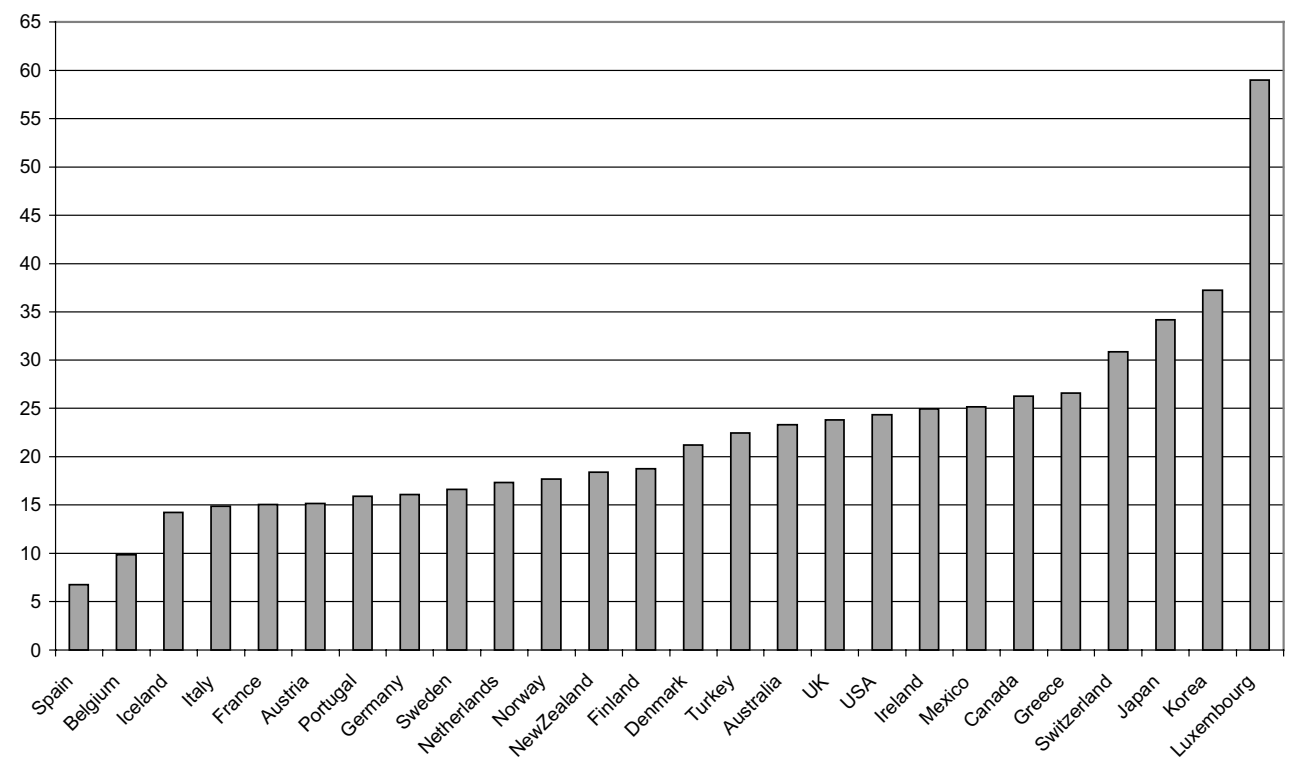

Fig. 4. Employees per branch, OECD countries (Based on data for all banks, 1995).

\footnotetext{
${ }^{5}$ Linear (rather than log-linear) regression results were qualitatively the same as those reported here.
} 
Table 1

Bank structure variables versus 5 exogenous variables.

\begin{tabular}{lcccc}
\hline & \multicolumn{3}{c}{ Dependent variables: alternative measures of banking structure } \\
\cline { 2 - 5 } $\begin{array}{l}\text { Exogenous } \\
\text { variables }\end{array}$ & $\begin{array}{c}\text { Equation } 1.1 \\
\text { Assets }\end{array}$ & $\begin{array}{c}\text { Equation } 1.2 \\
\text { Banks }\end{array}$ & $\begin{array}{c}\text { Equation } 1.3 \\
\text { Branches }\end{array}$ & $\begin{array}{c}\text { Equation 1.4 } \\
\text { Employees }\end{array}$ \\
\hline GDP & 1.21 & 1.54 & 0.64 & 0.52 \\
Pop & $(7.5)$ & $(4.9)$ & $(4.7)$ & $(4.8)$ \\
Area & -0.16 & -0.73 & 0.31 & 0.37 \\
GSR & $(1.0)$ & $(2.2)$ & $(2.2)$ & $(3.4)$ \\
Foreign & -0.09 & -0.21 & -0.11 & 0.02 \\
Constant & $(0.88)$ & $(1.1)$ & $(1.3)$ & $(0.25)$ \\
& 0.06 & 0.004 & -0.02 & 0.03 \\
Adjusted $R^{2}$ & $(2.8)$ & $(0.10)$ & $(1.2)$ & $(1.9)$ \\
& 2.1 & -1.13 & -0.34 & $(1.51$ \\
& $(2.8)$ & $(0.77)$ & $-0.54)$ & -6.3 \\
& -1.4 & -4.3 & $(0.58)$ & $(6.8)$ \\
& $(1.0)$ & $(1.6)$ & 0.913 & 0.941 \\
\hline
\end{tabular}

Branches, and Employees fit the data well, with adjusted $R^{2}$ above 0.90. The sign and significance of the key coefficients reflect our expectations, with two notable exceptions.

One exception is the effect of Area, with an insignificant coefficient in all equations, which may be especially unexpected in the Branches and Employees equations. The lack of significance for the physical size of the country was a consistent result across various specifications (not reported here); for example, allowing Area to enter nonlinearly did not change the result. We conjecture that in physically large countries (such as Canada, the United States, Australia and Mexico) much of the additional square mileage is best viewed as empty space, creating no major demand for banking services beyond the effects already captured in population and income. ${ }^{6}$

The other odd result occurs in the equation for Banks (Equation 1.2), where GDP is the only significant coefficient with a positive sign. It is also noteworthy that the adjusted $R^{2}$ in the equation for Banks is about 0.62, much lower than for any of the other equations. This suggests that other factors have a strong influence on the number of banks. For example, within the United States, states that had in-state branching restrictions also had a larger number of banking firms, with stand-alone banks taking the place of branches. On a cross-country basis, branching regulations are probably not as critical, but it is quite possible that other aspects of policy, such as antitrust and the treatment of foreign banks, have been important in determining the number of banking firms.

Our ultimate goal is to create benchmarks for banking sector structure in transition economies. The fact that banks in the developed economies now operate in relatively

\footnotetext{
${ }^{6}$ In contrast, in their study of the number of branches in Chicago neighbourhoods, Kaufman and Mote (1994) found area was a significant factor as part of a population density variable.
} 
free and competitive markets compared to most transition economies allows us to use the observed structure of banking systems in the former as a standard for measuring the efficiency of the banking systems in the latter. If the structure and function of banking sectors in transition economies ultimately come to resemble those in more developed countries, relationships among the variables should be similar to those in the OECD sample of developed economies.

For this purpose, we re-estimated the equations in Table 1, dropping any variables that had negative coefficients. ${ }^{7}$ The resulting final estimates are shown in Table 2 . The coefficients and $t$-statistics provide insight into the quantitative effect of the exogenous variables on banking structure. As in Table 1, GDP is an important determinant of all four structure measures. The estimated coefficients indicate that a $10 \%$ increase in GDP is associated with an equal percentage increase in banking system assets, but smaller percentage increases in the number of banks, branches, and employees, $(8,6$ and $5 \%$ respectively). The fact that assets increase by a larger percentage than the number of banks implies a larger average size for banks in larger economies. Pop has a positive and significant effect on Branches and Employees, although elasticities of 0.28 and 0.37 imply that population growth does not have a proportional effect on these aspects of banking system structure. Area enters only in the equation for Employees, and its effect is small and insignificant. An increase in the savings rate of $6 \%$ (about one standard deviation for GSR in this OECD sample) is associated with a $42 \%$ increase in banking system assets and a roughly $18 \%$ increase in banking employment, as well as a less significant increase in the number of banks. Finally, the significant

Table 2

Bank structure variables with positively signed exogenous variables.

\begin{tabular}{|c|c|c|c|c|}
\hline \multirow[b]{2}{*}{$\begin{array}{l}\text { Exogenous } \\
\text { variables }\end{array}$} & \multicolumn{4}{|c|}{ Dependent variables: alternative measures of banking structure } \\
\hline & $\begin{array}{c}\text { Equation } 2.1 \\
\text { Assets }\end{array}$ & $\begin{array}{c}\text { Equation } 2.2 \\
\text { Banks }\end{array}$ & $\begin{array}{c}\text { Equation } 2.3 \\
\text { Branches }\end{array}$ & $\begin{array}{c}\text { Equation } 2.4 \\
\text { Employees }\end{array}$ \\
\hline$G D P$ & $\begin{array}{r}1.03 \\
(14.8)\end{array}$ & $\begin{array}{r}0.80 \\
(5.3)\end{array}$ & $\begin{array}{r}0.62 \\
(4.9)\end{array}$ & $\begin{array}{r}0.52 \\
(4.8)\end{array}$ \\
\hline Pop & & & $\begin{array}{c}0.28 \\
(2.4)\end{array}$ & $\begin{array}{r}0.37 \\
(3.4)\end{array}$ \\
\hline Area & & & & $\begin{array}{c}0.02 \\
(0.25)\end{array}$ \\
\hline$G S R$ & $\begin{array}{r}0.07 \\
(4.2)\end{array}$ & $\begin{array}{c}0.04 \\
(1.2)\end{array}$ & & $\begin{array}{r}0.03 \\
(1.9)\end{array}$ \\
\hline Foreign & $\begin{array}{c}2.7 \\
(4.5)\end{array}$ & $\begin{array}{c}0.97 \\
(1.3)\end{array}$ & & $\begin{array}{c}0.51 \\
(1.0)\end{array}$ \\
\hline Constant & $\begin{array}{c}-2.2 \\
(2.2)\end{array}$ & $\begin{array}{l}-5.9 \\
(2.7)\end{array}$ & $\begin{array}{c}-1.9 \\
(2.6)\end{array}$ & $\begin{array}{c}-6.3 \\
(6.8)\end{array}$ \\
\hline Adjusted $R^{2}$ & 0.903 & 0.523 & 0.917 & 0.941 \\
\hline
\end{tabular}

\footnotetext{
${ }^{7}$ When re-estimating equation (1.2), we found that the variable Foreign obtained a positive sign when Pop and Area were dropped from the equation; Foreign was retained in the final specification shown as equation (2.2) in Table 2.
} 
coefficient on Foreign in the Assets equation (Eq 2.1) implies that a 20\% (roughly one standard deviation) increase in foreign deposits as a share of bank liabilities is associated with an increase of just over $50 \%$ in banking assets.

\section{Benchmarks for banking sector structure in transition economies}

We now apply our regression estimates to compute benchmark values for the banking structure in a sample of 23 transition economies. In Table 3, the columns titled Benchmark summarise the results of applying actual data values for the exogenous variables from the 23 transition economies into the right-hand-side variables of the final regression equations shown in Table 2. The benchmarks show what banking structure would be if the banking sector in the transition economy looked like that in a developed country with similar characteristics and size. This is just a direct substitution, although several data issues do arise. ${ }^{8}$ The transition economy data come primarily from IMF, OECD, and central bank sources, and details are provided in the Data Appendix. Although all the equations were estimated in logs, the results in Table 3 are displayed in the natural units for each variable.

Table 3 also shows the actual values for the transition economy banking variables for which we have been able to obtain data. We have been able to obtain a complete set of actual values for bank assets and the number of commercial banks. Data for the number of bank branches and bank employees are much more sketchy. Using the benchmark and actual data, we can create measures of 'convergence' - how close the actual results for each country are to the corresponding benchmark value. Three important questions can be posed. The first is whether the observed degree of convergence between actual bank structure and the benchmarks is a function of how advanced each country is in the transition process. The second is whether our convergence measures correlate closely with other available measures of banking sector development in the transition economies. The third is whether a higher degree of banking structure convergence correlates with higher economic growth for the transition economy.

\section{Bank assets}

We begin the discussion with bank assets. Table 4 provides an expanded set of data for analysing the relationship between the actual and benchmark values of bank assets. Column (2) in Table 4 is a measure of the difference between actual bank assets and our benchmark values (based on the data from Table 3), hereafter referred to as the asset ratio:

$$
\text { Asset ratio }=1-\operatorname{abs}\left(\frac{\text { Benchmark }- \text { Actual }}{\text { Actual }}\right)
$$

\footnotetext{
${ }^{8}$ The data are adjusted as follows: (1) The exogenous variable Foreign has been set to zero for all the transition economies, on the presumption that none of these economies is currently serving as an international financial center. (2) The gross savings rate variable GSR has been set equal to zero for the several transition economies in which the actual GSR was negative. (3) The GDP variable has been adjusted for the known undercount in the transition economies by using available electricity data. The Data Appendix discusses the transition country data in more detail.
} 
Table 3

Actual and benchmark banking structure, transition economies, 1995.

\begin{tabular}{|c|c|c|c|c|c|c|c|c|}
\hline \multirow[b]{2}{*}{ Country } & \multicolumn{2}{|c|}{$\begin{array}{c}\text { Assets } \\
\text { (US\$ millions) }\end{array}$} & \multicolumn{2}{|c|}{ Banks } & \multicolumn{2}{|c|}{ Branches } & \multicolumn{2}{|c|}{ Employees ('000) } \\
\hline & Actual & Benchmark & Actual & Benchmark & Actual & Benchmark & Actual & Benchmark \\
\hline Albania & 1658 & 928 & 9 & 3 & & 300 & & 7 \\
\hline Armenia & 145 & 548 & 33 & 3 & & 301 & & 8 \\
\hline Azerbaijan & 755 & 1914 & 136 & 5 & & 497 & & 15 \\
\hline Belarus & 3762 & 14695 & 38 & 21 & & 1064 & & 43 \\
\hline Bulgaria & 5753 & 10956 & 47 & 17 & & 834 & & 33 \\
\hline Croatia & 11931 & 3883 & 60 & 9 & & 733 & & 18 \\
\hline Czech Rep & 55171 & 62454 & 51 & 55 & 1518 & 1595 & 60 & 77 \\
\hline Estonia & 1245 & 1907 & 14 & 5 & & 209 & & 7 \\
\hline Georgia & 150 & 1725 & 61 & 3 & & 365 & & 10 \\
\hline Hungary & 25792 & 68912 & 43 & 62 & & 1798 & 36 & 83 \\
\hline Kazakstan & 2311 & 20342 & 101 & 29 & 949 & 1394 & & 64 \\
\hline Krgyz Rep & 235 & 608 & 18 & 4 & 165 & 402 & & 10 \\
\hline Latvia & 1519 & 2363 & 33 & 7 & & 377 & & 11 \\
\hline Lithuania & 1642 & 3121 & 12 & 7 & & 413 & & 13 \\
\hline Moldova & 371 & 1323 & 21 & 5 & & 317 & & 12 \\
\hline Mongolia & 226 & 1584 & 13 & 3 & & 156 & & 7 \\
\hline Poland & 50537 & 83897 & 81 & 82 & 4512 & 4245 & 136 & 186 \\
\hline Russia & 75076 & 666249 & 2030 & 367 & & 15461 & & 878 \\
\hline Slovak Rep & 12256 & 20935 & 29 & 25 & & 713 & & 34 \\
\hline Slovenia & 10786 & 16624 & 29 & 22 & 550 & 581 & 10 & 20 \\
\hline Tajikistan & 335 & 2658 & 23 & 6 & & 334 & & 15 \\
\hline Ukraine & 6761 & 68076 & 188 & 101 & & 5062 & & 241 \\
\hline Uzbekistan & 1883 & 7428 & 29 & 13 & & 1233 & & 47 \\
\hline
\end{tabular}

For data sources, see Data Appendix.

Benchmark values for assets, banks, branches and employees were computed by applying equations (2.1), (2.2), (2.3) and (2.4) respectively based on transition economy data.

The asset ratio is thus a measure of the percentage change in bank assets from the current level that would be required to achieve convergence to the benchmark value; a country with perfect convergence $($ Actual $=$ Benchmark) receives an asset ratio of 1.0. Negative values for the asset ratio indicate that the current deviation is more than $100 \%$ of the current actual. The actual is lower than the benchmark in all cases except Albania and Croatia.

The countries in Column (1) of Table 4 have been placed in rank order based on the asset ratio in Column (2). The data in Columns (3) to (9) of Table 4 provide additional information for gauging the comparative progress of the transition economies. Column (3) shows a clear regional pattern, where the greatest convergence of banking structure to the benchmarks (as measured by the asset ratio) has occurred in Central and Eastern Europe and the Baltic States, while the least convergence has been in Central Asia and the Commonwealth of Independent States. This is consistent with the general impression that the Baltics and Central and Eastern Europe have made the greatest overall progress in the transition process. 
Table 4

Bank assets: comparing actual and benchmark values for transition economies.

\begin{tabular}{|c|c|c|c|c|c|c|c|c|}
\hline Country & $\begin{array}{l}\text { Asset ratio } \\
\text { (see below) }\end{array}$ & Region & $\begin{array}{l}\text { GDP per } \\
\text { capita }\end{array}$ & $\begin{array}{l}{[5]} \\
\text { Priv. sect. } \\
\text { share of } \\
\text { GDP }\end{array}$ & $\begin{array}{c}\text { [6] } \\
\text { EBRD } \\
\text { large-scale } \\
\text { privatisation }\end{array}$ & $\begin{array}{c}\text { [7] } \\
\text { EBRD } \\
\text { small-scale } \\
\text { privatisation }\end{array}$ & $\begin{array}{c}{[8]} \\
\text { Legal } \\
\text { transition } \\
\text { indicator }\end{array}$ & $\begin{array}{l}{[9]} \\
\text { EBRD } \\
\text { banking } \\
\text { rating }\end{array}$ \\
\hline Czech Rep & 0.87 & CEE & 4885 & 75 & 4.00 & 4.25 & 4.00 & 3.00 \\
\hline Albania & 0.56 & CEE & 1751 & 75 & 2.00 & 4.00 & 2.00 & 2.00 \\
\hline Estonia & 0.47 & Baltic & 3055 & 70 & 4.00 & 4.25 & 2.00 & 3.25 \\
\hline Slovenia & 0.46 & CEE & 10499 & 50 & 3.25 & 4.25 & 3.00 & 3.00 \\
\hline Latvia & 0.44 & Baltic & 3707 & 55 & 3.00 & 4.00 & 3.00 & 3.00 \\
\hline Poland & 0.34 & CEE & 3487 & 65 & 3.25 & 4.25 & 4.00 & 3.00 \\
\hline Croatia & 0.33 & CEE & 4266 & 55 & 3.00 & 4.25 & 4.00 & 2.75 \\
\hline Slovak Rep & 0.29 & CEE & 3443 & 75 & 4.00 & 4.25 & 3.00 & 2.75 \\
\hline Lithuania & 0.10 & Baltic & 2434 & 70 & 3.00 & 4.00 & 3.00 & 3.00 \\
\hline Bulgaria & 0.10 & CEE & 2305 & 50 & 3.00 & 3.00 & 3.00 & 2.75 \\
\hline Azerbaijan & -0.53 & Caucasus & 1174 & 40 & 2.00 & 3.00 & 1.00 & 2.00 \\
\hline Krgyz Rep & -0.59 & Cen Asia & 1746 & 60 & 3.00 & 4.00 & 2.00 & 2.75 \\
\hline Hungary & -0.67 & CEE & 6019 & 75 & 4.00 & 4.25 & 4.00 & 4.00 \\
\hline Moldova & -1.56 & CIS & 1259 & 45 & 3.00 & 3.00 & 2.00 & 2.00 \\
\hline Armenia & -1.78 & Caucasus & 1425 & 55 & 3.00 & 3.00 & 3.00 & 2.25 \\
\hline Belarus & -1.91 & CIS & 2329 & 20 & 1.00 & 2.00 & 2.00 & 1.00 \\
\hline Uzbekistan & -1.94 & Cen Asia & 1014 & 45 & 2.75 & 3.00 & 2.00 & 1.75 \\
\hline Mongolia & -5.01 & Cen Asia & 911 & NA & NA & NA & NA & NA \\
\hline Tajikistan & -5.94 & Cen Asia & 892 & 20 & 2.00 & 2.00 & NA & 1.00 \\
\hline Kazakhstan & -6.80 & Cen Asia & 1963 & 55 & 3.00 & 3.25 & 2.00 & 2.25 \\
\hline Russia & -6.87 & CIS & 3983 & 70 & 3.25 & 4.00 & 3.00 & 2.25 \\
\hline Ukraine & -8.07 & CIS & 3042 & 50 & 2.25 & 3.25 & 2.00 & 2.00 \\
\hline Georgia & -9.50 & Caucasus & 1151 & 55 & 3.25 & 4.00 & 2.00 & 2.25 \\
\hline \multirow{3}{*}{\multicolumn{3}{|c|}{$\begin{array}{l}\text { Correlation of Column [2] with } \\
\text { Simple correlation } \\
\text { Rank correlation }\end{array}$}} & Column 4 & Column 5 & Column 6 & Column 7 & Column 8 & Column 9 \\
\hline & & & 0.337 & 0.296 & 0.224 & 0.331 & 0.352 & 0.474 \\
\hline & & & 0.404 & 0.284 & 0.439 & 0.386 & 0.278 & 0.643 \\
\hline
\end{tabular}

Baltic $=$ Baltic States

Caucasus $=$ Caucasus mountains and Black Sea

$\mathrm{CEE}=$ Central and Eastern Europe

Cen Asia $=$ Central Asia

CIS $=$ Commonwealth of Independent States

$$
\text { Asset ratio }=1-a b s\left(\frac{\text { Benchmark }- \text { Actual }}{\text { Actual }}\right)
$$

The remaining columns of Table 4 provide alternative quantitative measures of the progress each country has made in various aspects of the transition process. Column (4) shows GDP per capita (\$US for the year 1995) as one general indicator of transition progress. Columns (5) to (9) provide data taken from the 1997 Transition Report published by the European Bank for Reconstruction and Development (EBRD, 1997). Column (5) shows the share of GDP coming from the private sector. Columns (6) and (7) show index numbers for the extent of large-scale and small-scale privatisation carried out in each economy (1 is lowest, higher numbers are better). Column (8) shows the progress made in transforming the legal system in each 
transition economy, while Column (9) shows the EBRD banking rating (again, 1 is lowest).

Simple and rank correlations with the asset ratio are shown at the bottom of each column. For columns (4) through (8), we expect a positive correlation between the asset ratio and each measure of general progress in the transition process, under the hypothesis that progress in banking sector transition also requires progress in the general transition process. The results for both the simple and rank correlations fully bear out this expectation. The rank correlations tend to be larger than the simple correlations; the rank orderings tend to convey more useful information than the cardinal orderings, largely because the units of the alternative measures are arbitrary. Overall, we interpret these results as confirmation that our asset ratio provides meaningful information concerning the convergence of transition country banking systems toward developed economy standards.

Column (9) in Table 4 shows the EBRD Bank Reform Index, a subjective evaluation made by the EBRD staff of the development status of each transition country's banking system. The positive and relatively high correlations shown at the bottom of Column (9) indicate a common set of information is contained in the two measures. Indeed, the correlations (both simple and rank) are the highest of all the correlations shown. We have no direct way to determine which of the two measures of bank transition progress is more accurate-indeed, they are likely to measure different aspects of the development process. It is noteworthy, however, that our asset ratio is an objective measure that can be replicated consistently over time, thus providing a time series as well as cross section measure of the convergence process.

\section{Number of banks}

The benchmark values for the number of banks in the transition economies are shown in the second pair of columns of Table 3. For most of the transition economies (all but Hungary, Poland and the Czech Republic), the actual number of banks exceeds our benchmark values, suggesting a systematic overshooting in the transition process. Table 5 provides an expanded set of data for analysing the relationship between the actual and benchmark values of the number of banks. Column (2) in Table 5 is a measure of the difference between the actual number of banks and our benchmark values (based on the data from Table 3), hereafter referred to as the bank ratio:

$$
\text { Bank ratio }=1-\text { abs }\left(\frac{\text { Benchmark }- \text { Actual }}{\text { Actual }}\right) .
$$

The bank ratio is thus a measure of the percentage change in the number of banks from the current level that would be required to achieve convergence to the benchmark value. It is defined in full analogy with our definition of the asset ratio above, and the interpretation of the values is exactly the same.

The countries in Column (1) of the table have been placed in rank order based on the bank ratio in Column (2). The other columns of Table 5 are as in Table 4. As before, there is a clear indication that the greatest banking convergence (as measured by the bank ratio) has occurred in Central and Eastern Europe and the Baltic States, while the least convergence generally has been in Central Asia and the Commonwealth of Independent States. 
Table 5

Analysing the number of banks in transition economies.

\begin{tabular}{|c|c|c|c|c|c|c|c|c|}
\hline Country & $\begin{array}{l}\text { Bank ratio } \\
\text { (see below) }\end{array}$ & Region & $\begin{array}{l}\text { GDP per } \\
\text { capita }\end{array}$ & $\begin{array}{c}{[5]} \\
\text { Priv. sect. } \\
\text { share of } \\
\text { GDP }\end{array}$ & $\begin{array}{c}{[6]} \\
\text { EBRD } \\
\text { large-scale } \\
\text { privatisation }\end{array}$ & $\begin{array}{c}{[7]} \\
\text { EBRD } \\
\text { small-scale } \\
\text { privatisation }\end{array}$ & $\begin{array}{c}{[8]} \\
\text { Legal } \\
\text { transition } \\
\text { indicator }\end{array}$ & $\begin{array}{c}{[9]} \\
\text { EBRD } \\
\text { banking } \\
\text { rating }\end{array}$ \\
\hline Poland & 0.99 & CEE & 3487 & 65 & 3.25 & 4.25 & 4.00 & 3.00 \\
\hline Czech Rep & 0.91 & CEE & 4885 & 75 & 4.00 & 4.25 & 4.00 & 3.00 \\
\hline Slovak Rep & 0.85 & CEE & 3443 & 75 & 4.00 & 4.25 & 3.00 & 2.75 \\
\hline Slovenia & 0.76 & CEE & 10499 & 50 & 3.25 & 4.25 & 3.00 & 3.00 \\
\hline Lithuania & 0.57 & Baltic & 2434 & 70 & 3.00 & 4.00 & 3.00 & 3.00 \\
\hline Hungary & 0.55 & CEE & 6019 & 75 & 4.00 & 4.25 & 4.00 & 4.00 \\
\hline Belarus & 0.54 & CIS & 2329 & 20 & 1.00 & 2.00 & 2.00 & 1.00 \\
\hline Ukraine & 0.54 & CIS & 3042 & 50 & 2.25 & 3.25 & 2.00 & 2.00 \\
\hline Uzbekistan & 0.46 & Cen Asia & 1014 & 45 & 2.75 & 3.00 & 2.00 & 1.75 \\
\hline Bulgaria & 0.35 & CEE & 2305 & 50 & 3.00 & 3.00 & 3.00 & 2.75 \\
\hline Albania & 0.33 & CEE & 1751 & 75 & 2.00 & 4.00 & 2.00 & 2.00 \\
\hline Estonia & 0.32 & Baltic & 3055 & 70 & 4.00 & 4.25 & 2.00 & 3.25 \\
\hline Kazakhstan & 0.28 & Cen Asia & 1963 & 55 & 3.00 & 3.25 & 2.00 & 2.25 \\
\hline Tajikistan & 0.26 & Cen Asia & 892 & 20 & 2.00 & 2.00 & NA & 1.00 \\
\hline Mongolia & 0.26 & Cen Asia & 911 & NA & NA & NA & NA & NA \\
\hline Moldova & 0.25 & CIS & 1259 & 45 & 3.00 & 3.00 & 2.00 & 2.00 \\
\hline Krgyz Rep & 0.21 & Cen Asia & 1746 & 60 & 3.00 & 4.00 & 2.00 & 2.75 \\
\hline Latvia & 0.20 & Baltic & 3707 & 55 & 3.00 & 4.00 & 3.00 & 3.00 \\
\hline Russia & 0.18 & CIS & 3983 & 70 & 3.25 & 4.00 & 3.00 & 2.25 \\
\hline Croatia & 0.16 & CEE & 4266 & 55 & 3.00 & 4.25 & 4.00 & 2.75 \\
\hline Armenia & 0.08 & Caucasus & 1425 & 55 & 3.00 & 3.00 & 3.00 & 2.25 \\
\hline Georgia & 0.05 & Caucasus & 1151 & 55 & 3.25 & 4.00 & 2.00 & 2.25 \\
\hline Azerbaijan & 0.04 & Caucasus & 1174 & 40 & 2.00 & 3.00 & 1.00 & 2.00 \\
\hline \multirow{3}{*}{\multicolumn{3}{|c|}{$\begin{array}{l}\text { Correlation of Column [2] with } \\
\text { Simple correlation } \\
\text { Rank correlation }\end{array}$}} & Column 4 & Column 5 & Column 6 & Column 7 & Column 8 & Column 9 \\
\hline & & & 0.516 & 0.298 & 0.298 & 0.297 & 0.498 & 0.314 \\
\hline & & & 0.458 & 0.305 & 0.291 & 0.367 & 0.388 & 0.343 \\
\hline
\end{tabular}

Baltic $=$ Baltic States

Caucasus $=$ Caucasus mountains and Black Sea

$\mathrm{CEE}=$ Central and Eastern Europe

Cen Asia $=$ Central Asia

CIS $=$ Commonwealth of Independent States

$$
\text { Bank ratio }=1-\text { abs }\left(\frac{\text { Benchmark }- \text { Actual }}{\text { Actual }}\right)
$$

The remaining columns of Table 5 again show the alternative measures of the transition process, with simple and rank correlations with the bank ratio shown at the bottom of each column. The correlations are all positive, and tend to be about the same as for the asset ratio. Overall, we interpret these results as confirmation that our bank ratio, like the asset ratio, provides meaningful information about the degree of convergence.

Column (9) in Table 5 shows the EBRD Bank Reform Index, as in Table 4. The correlations (both simple and rank) tend to be about the same value as the average of the correlations in Columns (4) to (8). As with the asset ratio-and unlike the EBRD rating - our bank ratio is an objective measure that can be replicated consistently. 
These results bear out the expectation that countries with greater progress in the general transition process also have higher convergence of the number of banks to our benchmark. However, the correlations with the bank ratios here in Table 5 are generally lower than the corresponding correlations for the asset ratio in Table 4. This is not surprising, since political and regulatory forces, as opposed to fundamental economic forces, are likely to play a more important role in determining the number of banks.

Taken together, Tables 4 and 5 suggest that banking systems in the transition countries generally have too many banks and relatively low total banking assets, at least given the size and other characteristics of those economies. With both a large number of banks and relatively low aggregate assets, the average size of the banks in many transition economies is extremely small. This is illustrated in Figure 5, which shows that the average size of banks in Georgia, Armenia, and Azerbaijan is less than $\$ 5$ million in total assets, and that in more than half the countries the average size is under \$100 million. In comparison, among the OECD countries shown in Figure 2, even Iceland has an average asset size slightly greater than $\$ 100$ million, and only six countries (including the United States) have an average asset size less than $\$ 1$ billion.

\section{Bank branches and employees}

The third and fourth sections of Table 3 show the benchmark values for the number of bank branches and bank employees that we have computed from the respective equations in Table 2, as well as the corresponding actual values for those transition countries for which data are available. For several of the countries for which we do have data, the correspondence between the actual and benchmark values for both

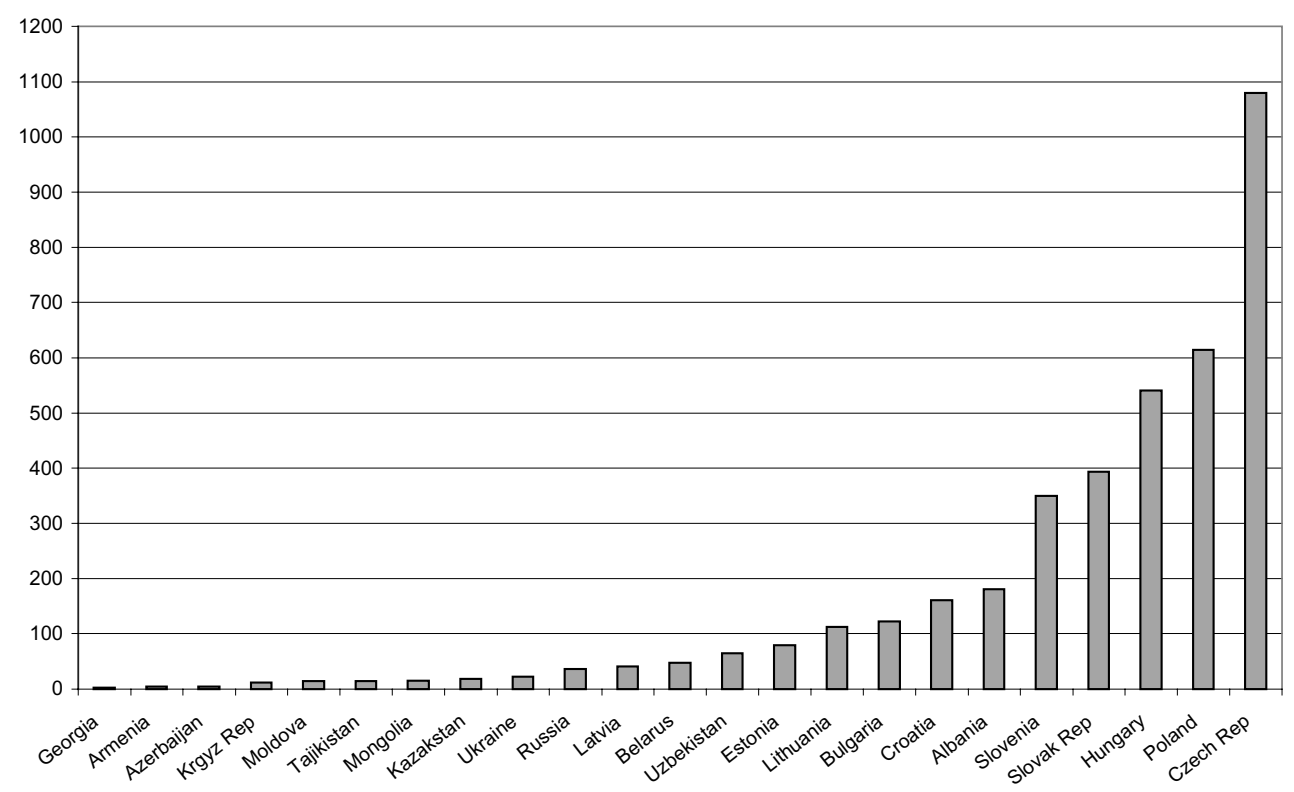

Fig. 5. Average bank size in transition countries, (US\$ millions)

(Based on actual values for 1995). 
branches and employees is relatively close. ${ }^{9} \mathrm{We}$ offer two plausible interpretations for the result, both of which may be part of a complete explanation:

1. Countries that are more advanced in the transition process are more likely to be able to produce and publish statistical data on their banking systems and other aspects of their economy. Thus, it is not surprising that the countries for which we have data show a degree of convergence in bank branches and bank employees similar to that in bank assets and number of banks.

2. The transition economies may generally be well advanced in translating the demand for banking services into the supply of bank branches and bank employees. This could be particularly true for payments system services, compared with intermediation and investment banking services, since some infrastructure for a payments system would already have existed in these countries under the previous regime of central planning; see for example Jaffee and Levonian (1997). This is consistent with a higher degree of convergence in bank branches and employees than in bank assets or number of banks.

\section{Banking structure and GDP per capita}

If efficient banking systems yield economic benefits, then countries with banking systems closer to the benchmarks should have faster growth. However, the transition process is at such an early stage in most of the Central and Eastern European countries, and the process has been so uneven, that income measures such as per capita GDP may be more informative than any measure of growth. Table 6 presents several regressions to explore the relationship between income and various measures of banking system structure. ${ }^{10}$

In Equation 6.1, GDP per capita is regressed on both the asset ratio and the bank ratio, from Tables 4 and 5. (Mongolia is excluded, because it is not rated by the EBRD.) Each variable has a positive effect, although only the bank ratio is significantly different from zero. Equation 6.2 shows the impact of adding the EBRD banking rating; this measure of banking system structure also is significantly and positively related to income, and the adjusted $R^{2}$ rises to 0.35 from 0.20 . However, the bank ratio remains significant, suggesting that the bank ratio and the EBRD rating are capturing different elements of the transition process with regard to banking. The last column in Table 6 (Equation 6.3) shows the effect if the asset ratio is dropped altogether.

The regression results indicate that, of the banking structure benchmarks we have been able to construct and test, the bank ratio is most closely related to the progress of economic development. It appears to measure important aspects of banking system development, aspects that are not wholly captured by more subjective measures such as the EBRD ranking. The significant positive relationship with per capita GDP provides additional evidence of the importance of an efficient banking system in the overall development process.

\footnotetext{
${ }^{9}$ For example, a 'branch ratio' constructed to be analogous to the asset ratio and bank ratio would exceed 0.9 for Slovenia, Poland, and the Czech Republic. Kazakstan and the Krgyz Republic would have much lower ratios ( 0.53 and -0.43 , respectively), which might be expected based on the results for the asset and bank ratios for those economies.

${ }^{10}$ The equations are estimated with ordinary least squares. Regressions fitted with instrumental variables to control for simultaneity bias yielded very similar results.
} 
Table 6

Banking structure and GDP per capita. Dependent variable: GDP per capita (in US\$ millions).

\begin{tabular}{lccc}
\hline & Equation 6.1 & Equation 6.2 & Equation 6.3 \\
\hline Constant & 1.74 & -18.45 & -15.67 \\
Asset ratio & $(1.96)$ & $(1.08)$ & $(1.17)$ \\
& 0.096 & -0.037 & \\
Bank ratio & $(0.69)$ & $(0.27)$ & 2.82 \\
& 3.55 & 2.94 & $(2.02)$ \\
EBRD rating & $(2.19)$ & $(2.00)$ & 1.39 \\
& & 1.46 & $(2.53)$ \\
Adjusted $R^{2}$ & & $(2.37)$ & 0.39 \\
\hline
\end{tabular}

\section{Conclusions}

The goal of this study has been to characterise the relationship between the banking systems in developed countries and various economic and other features of those countries, and then to use this characterisation to develop benchmarks for the structure of banking systems in transition economies. Benchmarks were estimated for a sample of 23 transition economies in Central and Eastern Europe. Correlations of the benchmarks with various measures of progress in the transition process confirmed the value of the benchmarks for evaluating transition country banking systems. Furthermore, regression tests demonstrated the positive relationship between the benchmark measures and the level of per capita GDP in the transition economies.

The methodology requires that the estimated equations for the developed economies represent dependable relationships between the four measures of banking system structure and our set of exogenous economic, demographic, financial, and geographic variables. The equations for bank assets, number of banks, number of branches, and bank employment all fit well, with significant coefficients of reasonable magnitude. Some caution was suggested, however, in applying the estimated equation for the number of banks.

Care must be taken, of course, in applying all of these equations to the transition economies. One caveat is that some of the variables we treat as 'exogenous', such as GDP and the savings rate, actually are endogenous to the development process. As the transition continues in these countries, these variables are likely to change, and the banking structure benchmarks also will change. However, this is also a strength of the regression approach, since the benchmarks can be recomputed easily with new values of any of the variables.

A second important caveat is that the benchmark values represent equilibrium values for a country's banking system. That is, the benchmarks reflect the structure of the banking sector as it would be if these countries followed the general pattern of the developed OECD countries. Some of the transition economies may be approaching equilibrium, in which case the benchmarks can be directly compared with the actual banking systems in these countries. This may be true, for example, in the Czech Republic, Hungary, and Poland. The relatively close fit of our benchmarks with the actual banking systems in these three countries creates further confidence in our methodology, as well as suggesting that the banking systems in these countries have an appropriate structure. 
On the other hand, the banking systems in many of the other transition countries are clearly still 'in process'. Our benchmark estimates for these banking systems are properly interpreted as values toward which the banking systems should be evolving in the longer run, but do not necessarily represent where their banking systems should be today. Thus, in cases where the current structure falls short of the benchmark, this should not be interpreted as a sign that privatisation has failed. Instead, our benchmark estimates should be used to monitor the progress of these countries as they adjust toward a western-style banking system.

\section{Data Appendix}

This appendix describes the data used in the study, separated into three main categories: developed country banking data, transition country banking data, and demographic and national income data.

\section{Developed country banking data}

The developed country banking data, covering bank assets, number of banks, bank branches, and bank employees, are used as the dependent variables for the estimation of the banking system structure equations in Section 2 of the study. The data cover 26 'primary' OECD countries, consisting of Australia, Austria, Belgium, Canada, Denmark, Finland, France, Germany, Greece, Iceland, Ireland, Italy, Japan, Korea, Luxembourg, Mexico, Netherlands, Norway, New Zealand, Portugal, Spain, Sweden, Switzerland, Turkey, United Kingdom, and USA. (The primary data set excludes data for the Czech Republic, Poland and Hungary, which are also now collected by the OECD, since these countries are used as part of our 'transition economy' panel.) The data refer to the year 1995, since this is the most recent year for which a complete and consistent data set is available.

The banking data are available in OECD (1997a) - Bank Profitability, Financial Statements of Banks, 1997 edition - and are also available on diskette. The data are collected to include all institutions which conduct ordinary banking business, namely institutions which primarily take deposits from the public at large and provide finance for a wide range of purposes'. Fortunately, this very well describes the set of 'banking' institutions required for our study. In particular, we have used the OECD defined group of 'other monetary institutions' (other than the Central Bank), which covers three main categories of institutions:

- Commercial banks (both domestic and foreign);

- Savings institutions (mutual savings banks, building societies and savings and loan associations);

- Co-operative banks.

We thereby exclude the OECD group of 'other financial institutions', which covers:

- Credit unions;

- Specialised credit institutions (typically for mortgage or development loans);

- Finance companies;

- Security market firms;

- Insurance and pension firms.

(C) Blackwell Publishers Ltd, 2001 
We are also excluding specialised payment networks, including automated teller machines, giro systems, and post office payment networks (the latter two being popular in some European countries), since they do not provide a range of banking services.

We focus on four specific measures of banking system structure:

- Total banking system assets;

- Number of banks;

- Number of branches; ${ }^{11}$

- Number of employees. ${ }^{12}$

The data for these four variables are provided in two different locations within OECD (1997a): in Part I (Statistics on Financial Statement of Banks) and Part II (General Tables). We have generally used the values in Part II, since they tend to be the most detailed. However, there were cases in which the data in Part I were more complete, and in those cases we used the Part I data.

The Bank for International Settlements (BIS) provides an alternative data source through its Committee on Payment and Settlement Systems. Since 1995, this Committee has published detailed data on the payment systems of Australia, Belgium, Canada, Finland, France, Germany, Iceland, Italy, Japan, Korea, Netherlands, Norway, Sweden, Switzerland, United Kingdom, and United States (see BIS, 1997). Generally, the BIS and OECD data are in close agreement. However, there is a significant disagreement for Belgium and the United Kingdom. For Belgium, it appears that the OECD data significantly over-count the number of branches, perhaps because part-time agencies or post office agencies were included in the branch count. Therefore, we have used the lower BIS estimate for the number of Belgium bank branches. In the case of the United Kingdom, it seems that the OECD data excluded building societies. Therefore, we have used the BIS data to obtain complete coverage for the number of banking institutions and the number of branches. Data on employment and total assets for UK building societies were obtained from United Kingdom (1998).

The OECD and BIS data were not sufficient in the cases of three countries, namely, Australia, Canada, and New Zealand. For these countries, actual numbers were obtained from the countries' statistical yearbooks, central bank bulletins, and bank association publications. Ireland was not represented at all in either the OECD or BIS data. However, a full set of Irish data were found in Banking Federation of the European Union (1996). This source also contained data for ten other European countries, all of which were consistent with our other data sources.

The data on the proportion of a country's bank liabilities held by foreigners for the variable Foreign were obtained from OECD (1997a) for most of the sample. However, for a subset of these countries, the data were available only in the OECD Flow of Funds accounts (OECD, 1997b). Furthermore, data for Japan, Korea, and Turkey were available only in their respective country statistical yearbooks (Japan Statistical Bureau, 1998; Korea National Statistical Office, 1995; and Turkey State Institute of Statistics, 1995), and data for the United States were available only in Federal Reserve (1997).

\footnotetext{
${ }^{11}$ This includes all full time branches, but excludes 'agencies' and similar part-time branches that are operated by non-bank employees (such as store or post office workers).

${ }^{12}$ This includes full time and part time employees, but excludes temporary workers.
} 


\section{Transition country banking data}

Data on bank assets for all transition countries were obtained from IMF (1997), except that data for Georgia, Tajikistan, and Uzbekistan are from Knight (1997). We use 1996 data for Bulgaria, since the 1995 data are considered unreliable. All asset data were converted from the country's currency to millions of US dollars, using the exchange rates published by the World Bank (which includes corrections for cases where the published rates are not representative).

Data on the number of banks are from Knight (1997), with the following exceptions: data for the Czech Republic, Hungary, and Poland are from OECD (1997a), Albanian data are from Lafferty (1997), Bulgarian data are from Bulgaria (1997), and Mongolian data are from Economist (1997). For the number of bank branches, the Czech Republic and Polish data are from OECD (1997a), Slovenian data are from ZBS Bank Association of Slovenia, Kazak data are from Hoelscher (1998), and data for the Krgyz Republic are from BISNIS (1998). For the number of bank employees, data for the Czech Republic, Hungary, and Poland were obtained from OECD (1997a) and data for Slovenia are from ZBS Bank Association of Slovenia.

\section{Demographic and national income data}

Population figures for all countries (in thousands) came from World Bank (1998), as reported for 1995. GDP and geographic area data were available for most countries from the United Nations (1998); comparable data for Switzerland were filled in from other sources. For the OECD countries, data for gross savings rates were obtained from the pull-out table in OECD country studies.

For the transition economies, data for GDP (in millions of US dollars) and gross savings rates were obtained from World Bank (1998). The World Bank's GDP data for the transition economies, however, were further adjusted for the known undercount, using the data in ERBD (1997), Box 4.2, which uses the method of Kaufmann and Kaliberda (1996) based on electricity usage. For those countries not listed in ERBD (1997), we applied the same undercount ratio shown for the listed country with the closest level of GDP per capita.

\section{References}

Bank for International Settlements (BIS), Committee on Payment and Settlement Systems, Paper No. 24, Statistics on Payment Systems in the Group of Ten Countries, December 1997, ISSN 1024-3380 (available on line at http://www.bis.org/publ/index.htm).

Banking Federation of the European Union, Annual Report, 1996.

Berger, A., Kashyap, A. and Scalise, J., 'The transformation of the US banking industry: what a long, strange trip it's been', Brookings Papers on Economic Activity, Vol. 2, 1995.

Bulgaria Republic, Statistical Yearbook, 1997.

BISNIS, 1997 Kyrgzstan Country Commercial Guide, 1998, under web address http:// www.itaiep.doc.gov/bisnis/bisnis.html.

Dermine, J., European Banking in the 1990s, 2nd ed., (Oxford: Blackwell, 1993).

Economist, Country Profile Mongolia, (Economist Intelligence Unit, 1997).

European Bank for Reconstruction and Development, Transition Report 1997, (London, 1997).

Federal Reserve, The Federal Reserve Bulletin, 1997.

Hoelscher, D., 'Banking System Restructuring in Kazakhstan', IMF Working Paper WP/98/96, 1998. 
International Monetary Fund, International Financial Statistics year-end publication, 1997.

Jaffee, D. and Levonian, M., 'Russian banking', Federal Reserve Bank of San Francisco, Weekly Letter, 20 October, 1995.

Japan Statistical Bureau, Japan Statistical Yearbook 1998.

Kaufman, G., Banking Structures in Major Countries, (Norwell MA: Kluwer Academic Publishers, 1992).

Kaufman, G. and Mote, L., 'The geographic distribution of financial institutions in Chicago', Economic Perspectives, January 1994, pp. 10-27.

Kaufmann, D. and Kaliberda, A., "An "unofficial" analysis of economies in transition: an empirical framework and lessons for policy', Development Discussion Paper No. 558, (Harvard University: Harvard Institute for International Development, 1996).

Korea National Statistical Office, Korea Statistical Yearbook 1995.

Knight, Central Bank Reforms in the Baltics, Russia, and the Other Countries of the Former Soviet Union, IMF Occasional Paper No. 157, 1997.

Lafferty (1997), 'Banking in Eastern Europe', East European Banker, located through LexisNexis.

Levine, R. and Zervos, S., 'Stock markets, banks, and economic growth', American Economic Review, Vol. 88, (June 1998), pp. 537-558.

Lewis, A. and Pescetto, G., EU and US Banking in the 1990s, (London: Academic Press, 1996).

OECD, Bank Profitability: Financial Statements of Banks, (Paris, 1997a).

OECD, Flow of Funds Accounts, (Paris, 1997b).

Pawley, M., Financial Innovation and Monetary Policy, (London: Routledge, 1993).

Rajan, R. and Zingales, L., 'Financial dependence and growth', American Economic Review, Vol. 88, June 1998, pp. 559-586.

Schumpeter, J. A., A Theory of Economic Development, (Cambridge MA: Harvard University Press, 1911).

Turkey State Institute of Statistics, Statistical Yearbook of Turkey, (1995).

United Kingdom, Office for National Statistics, Annual Abstract of Statistics 1998.

United Nations, 'Infonation' database available on-line at www.un.org (1998).

World Bank, World Development Indicators, (Washington, 1998). 